\title{
In-vitro Relationship between Protein-binding and Free Drug Concentrations of a Water-soluble Selective Beta-adrenoreceptor Antagonist (Atenolol) and Its Interaction with Arsenic
}

\author{
M.A. Alam', M.A. Awal', N. Subhan ${ }^{3}$, and M. Mostofa ${ }^{2}$ \\ 'Department of Pharmacy, Stamford University Bangladesh, 5 I Siddeswari Road, Dhaka 1217, Bangladesh, \\ ${ }^{2}$ Department of Pharmacology, Bangladesh Agricultural University, Mymensingh 2202, Bangladesh, and \\ ${ }^{3}$ Pharmacy Discipline, Khulna University, Khulna, Bangladesh
}

\begin{abstract}
The degree of binding of a drug to plasma proteins has a marked effect on its distribution, elimination, and pharmacological effect since only the unbound fraction is available for distribution into extra-vascular space. The protein-binding of atenolol was measured by equilibrium dialysis in the bovine serum albumin (BSA). Free atenolol concentration was increased due to addition of arsenic which reduced the binding of the compounds to BSA. During concurrent administration, arsenic displaced atenolol from its high-affinity binding Site I, and free concentration of atenolol increased from $4.286 \pm 0.629 \%$ and $5.953 \pm 0.605 \%$ to $82.153 \pm 1.924 \%$ and $85.486 \pm 1.158 \%$ in absence and presence of Site I probe respectively. Thus, it can be suggested that arsenic displaced atenolol from its binding site resulting in an increase of the free atenolol concentration in plasma.
\end{abstract}

Key words: Arsenic; Atenolol; Bovine serum albumin; Drug interactions; Plasma protein-binding

\section{INTRODUCTION}

The pharmacokinetic properties of exogenous and endogenous compounds can be influenced by reversible binding to human serum albumin (HSA), which is thought to be one of the primary determinants of the pharmacokinetic properties of drugs (1-4). Therefore, when evaluating interactions among drugs, it is important to be aware of possible identities of their binding sites on the protein because any alteration in drug-binding to HSA, including binding of the antihypertensive drugs, could lead to a change in pharmacokinetic properties. Human serum albumin can be immobilized in spherical, macroporous microparticles of polyacrylamide of about $1 \mu \mathrm{m}$ in diameter with retention of its native properties (5). Results of different ex-

Correspondence and reprint requests should be addressed to:

Md. Ashraful Alam

Lecturer

Department of Pharmacy

Stamford University Bangladesh

Siddeswari Campus, 51, Siddeswari Road

Dhaka 1217

Bangladesh

Email: sonaliagun@yahoo.com periments suggest that human serum albumin has a limited number of binding sites $(4,6,7)$. On the basis of the probe-displacement method, there are at least three relatively-high specific drug-binding sites on the HSA molecule. These sites, commonly called warfarin, benzodiazepine, and digoxin-binding sites, are also denoted as Site I, Site II, and Site III respectively $(4,8,9)$. It has been shown that diazepam, digitoxin, and warfarin independently bind to albumin and can conveniently be used as markers of three separate, discrete binding sites on albumin (5). Since numbers of protein-binding sites are limited, competition will exist between two drugs, and the drug with higher affinity will displace the other, causing increased free drug concentration leading to higher toxicity (10-12).

Plasma protein-binding properties are related to plasma clearance, elimination half-life, apparent volume of the distribvution, and area under the curve. The beta-blockers comprise a group of drugs that are mostly used in treating cardiovascular disorders, such as hypertension, cardiac arrhythmias, or ischemic heart diseases. As a class, the beta-blockers are quite diverse from a pharmacokinetic perspective as they display a high range 
of values in plasma protein-binding, percentage of drug eliminated by metabolism, or unchanged in the urine and in hepatic excretion ratio. In clinical practice, the beta-adrenergic antagonists are an extremely important class of drugs due to their high extent of use. The non-selective beta-blockers, including propranolol, oxprenolol, pindolol, nadolol, timolol, and labetalol each antagonize both $\beta_{1}$ and $\beta_{2}$-adrenergic receptors (ARs). The selective antagonists, including metoprolol, atenolol, esmelol, and acebutolol, have much greater binding-affinity for the $\beta_{1}$-AR. The selective beta-blockers are normally indicated for patients in whom $\beta_{2}$-receptor antagonism might associate with an increased risk of adverse effects. Such patients include those with asthma, or diabetes, or with peripheral vascular diseases, or Raynaud's disease (13). Of all known beta-adrenolytics, propranolol has the highest lipohilicity and can cross the blood brain barrier (BBB) whereas atenolol is a highly hydrophilic drug (partition coefficient of 0.02) (14). Hydrophilic beta-blockers, such as atenolol, are advantageous in patients who suffer from central nervous side-effects (sleep disturbances, psychosis, depression, and hallucination) during therapy with lipophilic drugs (13).

Lipophilic drugs, such as propranolol, are extensively metabolized by the liver while hydrophilic beta-blockers, including atenolol, are predominantly excreted through the kidney (Table 1) $(15,16)$. In patients with normal renal function, the atenolol half-life was calculated to be about six hours following single 100-mg oral dose. This value increased markedly in patients with renal insufficiency, and the blood clearance of atenolol was found to have a significant correlation with the glomerular filtration rate (17).

Approximately 91-96\% of propranolol can be bound to serum albumin or other proteins, mainly to $ß_{1}$-acid glycoprotein and lipoproteins (18). It suggests that the lipids circulating in plasma may act as an additional depot for propanolol. Circulating free fatty acids could displace the hydrophilic drug from its protein-binding site $(18,19)$. Contrary to propranolol, atenolol is mostly excreted through kidneys, and its elimination could not only be influenced by displacement of the drug from albumin, but also by alterations in renal blood flow in patients with hyperlipidaemia (18).

An understanding of the binding chemistry of betablockers, i.e. atenolol, with protein may help clinicians to interpret and predict differences among patients in pharmacologic response to these drugs. Competitive displacement is more significant when two drugs are capable of binding to the same sites on the protein. Although information resource regarding the binding of drugs to HSA is extensive, the mechanism of drug-binding to HSA is still a subject of speculation and controversy $(10,11,20)$. Again, arsenic has a tendency to bind strongly to protein. In our rural people who are at a higher risk of arsenic ingestion in their daily water-use, the blood arsenic concentration increases $(10,11)$. Considering this, the purpose of our work was to investigate the effect of arsenic on the concentration of the common antihypertensive drug (atenolol, a beta-blocker). Human and bovine serum albumin exhibit similar binding chemistry due to the high percentage of sequence identities between the two proteins (21). Bovine serum albumin (BSA), in lieu of HSA, was used in this study because of its low cost and easy availability.

\section{MATERIALS AND METHODS}

\section{Drugs and reagents used in the experiment}

Atenolol (General Pharmaceutical Ltd., Bangladesh) warfarin, diazepam, disodium hydrogen phosphate $\left(\mathrm{Na}_{2} \mathrm{HPO}_{4}\right)$, potassium dihydrogen phosphate $\left(\mathrm{KH}_{2} \mathrm{PO}_{4}\right)$, cellulose nitrate membrane (Medicell International Ltd., Liverpool Road, London, UK; molecular wt 1,200 Daltons), bovine serum albumin (BSA) (fatty acid-free, fraction V, molecular wt 66,500 from Sigma Chemical Ltd., USA), arsenic trioxide $\left(\mathrm{As}_{2} \mathrm{O}_{3}\right)$, and sodium arsenate were used.

\section{Instruments used}

The following instruments were used: $\mathrm{p}^{\mathrm{H}}$ Meter (HANNA Microprocessor $\mathrm{p}^{\mathrm{H}}$ Meter, Portugal), SP8400 UV/VIS Spectrophotometer (Thermospectronic, England), Metabolic Shaking Incubator (Clifton

Table 1. Pharmacokinetic properties of atenolol (15)

\begin{tabular}{|lcccccccc|}
\hline Substance & $\begin{array}{c}\text { Resorption } \\
\%\end{array}$ & $\begin{array}{c}\text { Bioavailability } \\
\%\end{array}$ & $\begin{array}{c}\mathrm{T}_{1 / 2} \\
(\mathrm{~h})\end{array}$ & $\begin{array}{c}\text { Active me- } \\
\text { tabolite }\end{array}$ & $\begin{array}{c}\mathrm{PPB} \\
\%\end{array}$ & $\begin{array}{c}\mathrm{Vd} \\
\mathrm{l} / \mathrm{kg}\end{array}$ & $\begin{array}{c}\text { Total } \\
\text { clearance } \\
(\mathrm{mL} / \mathrm{min})\end{array}$ & $\begin{array}{c}\text { Renal } \\
\text { clearance } \\
(\mathrm{mL} / \mathrm{min}\end{array}$ \\
\hline Atenolol & 50 & 50 & $6-9$ & -- & 3 & 0.7 & $100-180$ & $100-170$ \\
\hline min=Minute; PPB=Plasma protein-binding & & & & & \\
\hline
\end{tabular}


Shaking Bath, Nical electro Ltd., England), and Micro Syringe (well. Liang. Jin. Yang.q.I., China.)

\section{Method used}

Equilibrium dialysis was employed in the study $(22,23)$.

\section{Site-specific probes method}

We have used different site-specific probes to enhance our understanding of the drug-BSA interaction and thereby characterization of binding sites of the drugs used in the study on the BSA molecule $(4,8,9,22,23)$.

Two site-specific probes were used. These are: (a) Warfarin sodium (Site I-specific probe) and (b) Diazepam (Site II-specific probe) that may be used for the identification of the binding sites of the drugs on BSA.

In the direct procedure, the ratio of BSA and probe (either warfarin or diazepam) was $1: 1\left(2 \times 10^{-5} \mathrm{M}\right.$ : $\left.2 \times 10^{-5} \mathrm{M}\right)$, and different concentrations of drug were added. In the reverse procedure, the ratio of BSA and drug was $1: 1\left(2 \times 10^{-5} \mathrm{M}: 2 \times 10^{-5} \mathrm{M}\right)$, and different concentrations of probe (Site I-specific warfarin sodium or Site II-specific diazepam) were added. After conducting equilibrium dialysis, the free concentration of probe were determined in direct procedure and reverse procedure respectively.

\section{Preparation of standard curve}

Standard curve has been prepared using various concentrations and their corresponding concentration at $\mathrm{pH} 6.4$ and 7.4. Ultraviolet (UV) spectrophotometric scanning of the drugs-atenolol, diazepam, and warfarin-showed maximum absorbance of the UV light at $275 \mathrm{~nm}, 235 \mathrm{~nm}$, and $308 \mathrm{~nm}$ respectively. Atenolol showed linearity at a concentration range of $10-80 \mu \mathrm{M} / \mathrm{mL}$ with a confidence level of 0.9984 and 0.9967 at $\mathrm{pH} 6.4$ and 7.4 with linear equation $(\mathrm{Y}=0.0107 \mathrm{X})$ and $(\mathrm{Y}=0.0146$ $\mathrm{X}$ ) respectively. A similar standard curve was also prepared both for diazepam and warfarin, and the concentration of those drugs were calculated using corresponding linear equations.

\section{Estimation of association constant of ateno- lol at $\mathrm{pH} 6.4$ and $27^{\circ} \mathrm{C}$ temperature}

Estimation of the association constant of atenolol was done at $\mathrm{pH}$ 6.4. Ten clean and dried test tubes were taken, and $3 \mathrm{~mL}$ of previously-prepared $2 \times 10^{-5}$ M BSA solution at $\mathrm{pH} 6.4$ was taken in each of them. Aatenolol stock solution $\left(1 \times 10^{-2} \mathrm{M}\right.$ or $1 \times 10^{-3}$
M) was added in different volumes to nine of the 10 test-tubes to have the following concentrations: $0.5 \times 10^{-5} \mathrm{M}, 1 \times 10^{-5} \mathrm{M}, 2 \times 10^{-5} \mathrm{M}, 3 \times 10^{-5} \mathrm{M}, 4 \times 10^{-5} \mathrm{M}$, $5 \times 10^{-5} \mathrm{M}, 6 \times 10^{-5} \mathrm{M}, 7 \times 10^{-5} \mathrm{M}, 8 \times 10^{-5} \mathrm{M}$, and $9 \times 10^{-5} \mathrm{M}$. The tenth test-tube containing only BSA solution at $\mathrm{pH} 6.4$ was marked as 'control'. After mixing the solutions, these were allowed to stand for 10 minutes for maximum binding of atenolol to BSA; $2 \mathrm{~mL}$ from each test-tube was pipetted out and poured onto previously-prepared semi-permeable membrane-tubes and, finally, both sides of the tubes were clipped properly so that there was no leakage. The membrane-tubes containing the drugprotein mixture were immersed in ten 50 -mL flasks containing $30 \mathrm{~mL}$ of phosphate buffer solution of $\mathrm{pH}$ 6.4. The mouths of the flasks were covered by foil-paper. These conical flasks were then placed in a metabolic shaker for dialysis for 10 hours at 27 ${ }^{\circ} \mathrm{C}$ and $20 \mathrm{rpm}$. Buffer samples were collected from each flask after complete dialysis. Free concentrations of atenolol were measured by a UV spectrophotometer at a wavelength of $275 \mathrm{~nm}$.

\section{Estimation of association constant of ateno- lol at pH 7.4 and $27^{\circ} \mathrm{C}$ temperature}

To determine the association constant of atenolol at $\mathrm{pH} 7.4$, a similar protocol as for estimation of the association constant of atenolol at $\mathrm{pH} 6.4$ was followed using the buffer solution of $\mathrm{pH}$ 7.4. When dialysis was completed, buffer solutions were collected from each conical flask, and the free concentration of atenolol was measured by a UV spectrophotometer at a wavelength of $275 \mathrm{~nm}$.

Determination of binding site of atenolol using warfarin sodium as a Site I-specific probe

To determine the binding site of atenolol, using warfarin sodium as a Site I-specific probe, the successive steps that were followed are described below.

From the previously-prepared $2 \times 10^{-5} \mathrm{M}$ BSA solution, $3 \mathrm{~mL}$ was taken in each of the eight cleaned and dried test-tubes; $1 \times 10^{-3} \mathrm{M}$ warfarin solution was added to seven of the eight test-tubes, and the final ratio of protein and warfarin was $1: 1\left(2 \times 10^{-5}\right.$ M: $2 \times 10^{-5} \mathrm{M}$ ) in each of these seven test-tubes. The eighth test-tube containing only BSA solution was marked as 'blank' or 'control'. These mixtures were allowed to stand for 10 minutes for allowing binding of the warfarin to its particular binding site. Atenolol solutions (either $2 \times 10^{-2} \mathrm{M}$ or $2 \times 10^{-3} \mathrm{M}$ ) were added with increasing concentrations into six of the seven test-tubes containing 1:1 mixture of pro- 
tein-warfarin. The final ratios of protein: warfarin: atenolol were 1:1:0, 1:1:1, 1:1:2, 1:1:3, 1:1:4, 1:1:5, and $1: 1: 6$. The remaining test-tube contained only protein-warfarin mixture (1:1). After pipetting, the solution was properly mixed and allowed to stand for 10 minutes to ensure maximum binding of atenolol to Site I and thereby displacing the probe from Site I on BSA. From each test-tube, 2-mL solution was taken into eight different semi-permeable membrane-tubes. The two ends of the membranetubes were clipped to ensure that there was no leakage, and the rest of the experiment was done as described above using phosphate buffer solution of $\mathrm{pH} 7.4$.

\section{Determination of binding site of atenolol us- ing diazepam as a Site II-specific probe}

To perform the experiment, the previously-described procedure has been followed successively using diazepam solution. The final ratios of protein: diazepam: atenolol were 1:1:0, 1:1:1, 1:1:2, $1: 1: 3,1: 1: 4,1: 1: 5,1: 1: 6$, and 1:1:9. Atenolol was not present in the first test-tube which contained only protein-diazepam mixture (1:1). At the end of dialysis, samples were collected from each flask. The free concentrations of diazepam were measured using a UV spectrophotometer at a wavelength of $235 \mathrm{~nm}$ (BP). Reverse experiment was also being conducted followed by a similar protocol by adding diazepam in an increasing concentration and measuring the free atenolol concentration by spectrophotometer.

Effect of arsenic on atenolol-binding to BSA in presence of Site I-specific probe warfarinsodium

From the previously-prepared $2 \times 10^{-5} \mathrm{M}$ BSA solution and $1 \times 10^{-2} \mathrm{M}$ warfarin solution, $2 \mathrm{~mL}$ and 12 $\mathrm{mL}$, respectively, were added to each of the seven cleaned and dried test-tubes. The final ratio between protein and warfarin was $1: 1\left(2 \times 10^{-5} \mathrm{M}: 2 \times 10^{-5} \mathrm{M}\right)$ in each of seven test-tubes so that Site I is sufficiently blocked by warfarin-sodium. The seventh test-tube containing only BSA solution was marked as blank. After that, atenolol was added in six of the seven test-tubes, and protein-warfarin-atenolol ratio was 1:1:1 $\left(2 \times 10^{-5} \mathrm{M}: 2 \times 10^{-5} \mathrm{M}: 2 \times 10^{-5} \mathrm{M}\right)$. Arsenic was added with an increasing concentration into five of the six test-tubes containing 1:2:1 mixture of protein-warfarin-atenolol to make the final ratio of protein-warfarin-atenolol arsenic 1:2:1:0, 1:2:1:1, $1: 2: 1: 2,1: 2: 1: 4,1: 2: 1: 6,1: 2: 1: 8,1: 2: 1: 10$. Arsenic was not added to one test-tube. The solutions were then properly mixed and allowed to stand for 15 minutes for the confirmation of maximum binding to BSA. After that, the solution was pipetted out and poured into seven semi-permeable membranetubes. The two ends of the membrane-tubes were clipped to ensure that there was no leakage, and the rest of the experiment was done as described above using phosphate buffer solution of $\mathrm{pH}$ 7.4.

Effect of arsenic on atenolol-binding to BSA in absence of Site I-specific probe warfarinsodium

To perform the experiment, the previously-described procedure was followed successively in absence and presence of warfarin sodium. Arsenic was added with an increasing concentration to five of the six test-tubes containing 1:1 mixture of proteinatenolol to make the final ratio of protein:atenolol: arsenic 1:1:0, 1:1:1, 1:1:2, 1:1:4, 1:1:6, 1:1:8, 1:1:10. Arsenic was not added to the first test-tube which contained only protein-atenolol mixture (1:1). At the end of dialysis, samples were collected from each flask. The free concentrations of atenolol were measured by a UV spectrophotometer at a wavelength of $275 \mathrm{~nm}(\mathrm{BP})$.

\section{RESULTS}

Both association constant $\left(\mathrm{k}_{\mathrm{a}}\right)$ and number of binding sites (n) of atenolol were determined using the Scatchard plot. To estimate the binding parameters of atenolol, equilibrium dialysis (ED) was used and the subsequent non-linear shape of the Scatchard plot describes both high- and low-affinity binding sites of drugs on protein molecule.

\section{Determination of association constant and number of binding site}

Atenolol was characterized by a high-affinity association constant $(\mathrm{k} 1)$ to BSA and the value at $\mathrm{pH} 7.4$ was (4.6 \pm 0.151$) \times 10-5 \mathrm{M}$ (Table 2) while the low-affinity association constant $(\mathrm{k} 2)$ for atenolol was found to be $(3.03 \pm 0.086) \times 10-5 \mathrm{M}$. For this drug, the number of high-affinity and low-affinity binding sites was $(0.61 \pm 0.199) \times 10-5 \mathrm{M}$ and $(1.33 \pm 0.114)$ $\mathrm{x} 10-5 \mathrm{M}$ respectively at $\mathrm{pH}$ 7.4. In the case of atenolol bound to BSA, the high-affinity association constant (k1) was found to increase when $\mathrm{pH}$ was changed from 7.4 to 6.4 , and the value for k1 and $\mathrm{k} 2$ was (5.06 \pm 0.202$) \times 10-5 \mathrm{M}$ and (4.23 \pm 0.159$)$ $\mathrm{x} 10-5 \mathrm{M}$ respectively (Table 2 ). As a consequence for this drug, the number of high-affinity and lowaffinity binding sites was $(0.81 \pm 0.04) \times 10-5 \mathrm{M}$ and (2.03 \pm 0.201$) \times 10-5 \mathrm{M}$ respectively at $\mathrm{pH}$ 6.4. When the changes of physiological pH occur, BSA undergoes conformational alteration, which is generally 
termed N-B transition. BSA remains almost entirely in neutral form at $\mathrm{pH} 6$ and in basic form at $\mathrm{pH}$ 9. When the protein is in the B-conformation, fewer protons are bound to BSA than that in the N-conformation. Thus, the high-affinity and lowaffinity binding of atenolol is affected by change in $\mathrm{pH}$. These differences in effect of $\mathrm{pH}$ may be due to the structural modification of protein molecule and, for this reason, at a given $\mathrm{pH}$ value, the binding site for atenolol is more suitable or properly accommodated, while at other $\mathrm{pH}$ values, the binding sites become less convenient and less accommodating to the drugs in concern.

\section{Determination of binding site}

Well-established probes, which are specific for particular sites on the albumin molecule, are used for the identification of the binding site of the drugs on the protein molecule. If a drug is able to displace a probe from its binding site, it is assumed that the drug also binds to that particular site. Thus, the binding site and specificity and relative strength of binding to albumin of atenolol have been determined by this principle. Here, as Site I-specific probe, warfarin sodium and as Site II-specific probe, diazepam, were used. To characterize the binding site of atenolol, the free concentration of warfarinsodium (Site I-specific probe) bound to BSA was measured upon the addition of atenolol. It was found that the free concentration of warfarin-sodium increased from $14.966 \pm 0.351 \%$ (as \% of initial) to $65.66 \pm 1.457 \%$ when the ratio of atenolol to BSA was increased to 6 (Fig. 1). In contrast, under the same experiment conditions when, in lieu of warfarin-sodium, diazepam was used as Site II-specific probe, the increment of the free concentration of diazepam by atenolol was from $11.166 \pm 0.152 \%$ (as \% of initial) to $40.1 \pm 1.014 \%$ (Fig. 1). From these data, this is evident that, upon addition of atenolol, the increment of free concentration of warfarin-sodium is obviously greater than that of diazepam. Thus, it can be concluded that atenolol preferentially binds to Site I. Again, as the displacement of diazepam is quite pronounced, it can be also suggested that atenolol, in addition to Site I, also binds to Site II on the BSA molecule but to a lower extent. In the reverse experiment, the free concentration of atenolol was increased from $8.7 \pm 0.529 \%$ (as \% of initial) to $71.133 \pm 1.059 \%$ when warfarin to BSA ratio was 6 (Fig. 2). On the other hand, the free concentration of atenolol was increased from $13.933 \pm 0.702 \%$ (as \% of initial) to $68.65 \pm 1.261 \%$ at the ratio of diazepam to BSA were also 6 (Fig. 2 ). From these data, it is clear that the increment of atenolol due to displacement by warfarin (Site I probe) is higher than that of atenolol when displaced by diazepam. Thus, the findings of the reverse experiment also were in agreement with the findings of the previous experiment.

\section{Displacement of atenolol due to the effect of arsenic}

During concurrent administration of atenolol and arsenic, site-to-site displacement takes place, and arsenic displaced atenolol from its binding sites (Fig. 3). In presence of probe, free concentration of atenolol was more prominent. This displacement may be due to reduction of the binding site on bovine serum albumin. As observed from the model (Fig. 4), during concurrent administration, arsenic displaced atenolol from its high-affinity binding Site I. Thus, free concentration of atenolol increased from $4.286 \pm 0.629 \%$ and $5.953 \pm 0.605 \%$ to $82.153 \pm 1.924 \%$ and $85.486 \pm 1.158 \%$ in absence and in presence of Site I probe respectively.

\section{DISCUSSION}

In-vitro binding of water-soluble selective beta-adrenergic-blocker drug with bovine serum albumin was studied, and a lower association constant at $\mathrm{pH} 6.4$ compared to $\mathrm{pH} 7.4$ was found with a limited number of corresponding binding sites. HSA is an abundant transport-protein found in plasma which binds a wide variety of drugs in two primary binding sites (I and II) that can have a significant impact on their pharmacokinetics (24). Site-specific displacement interaction also provides information about the binding site. Atenolol substantially binds with

\begin{tabular}{|c|c|c|c|c|}
\hline \multirow[b]{2}{*}{$\mathrm{pH}$} & \multicolumn{2}{|c|}{ Association constant } & \multicolumn{2}{|c|}{ No. of binding sites } \\
\hline & $\begin{array}{c}\mathrm{K}_{1} \\
\text { (high affinity) } \\
\times 10^{-5} \mathrm{M}\end{array}$ & $\begin{array}{c}\mathrm{K}_{2} \\
\text { (low affinity) } \\
\times 10^{-5} \mathrm{M}\end{array}$ & $\begin{array}{c}\mathrm{n}_{1} \\
\text { (high affinity) } \\
\times 10^{-5} \mathrm{M}\end{array}$ & $\begin{array}{c}\mathrm{n}_{2} \\
\text { (low affinity) } \\
\times 10^{-5} \mathrm{M}\end{array}$ \\
\hline 6.4 & $5.06 \pm 0.202$ & $4.23 \pm 0.159$ & $0.81 \pm 0.04$ & $2.03 \pm 0.201$ \\
\hline 7.4 & $4.6 \pm 0.151$ & $3.03 \pm 0.086$ & $0.61 \pm 0.199$ & $1.33 \pm 0.114$ \\
\hline
\end{tabular}

Values represent three consecutive experiments and expressed as mean \pm standard error of mean 


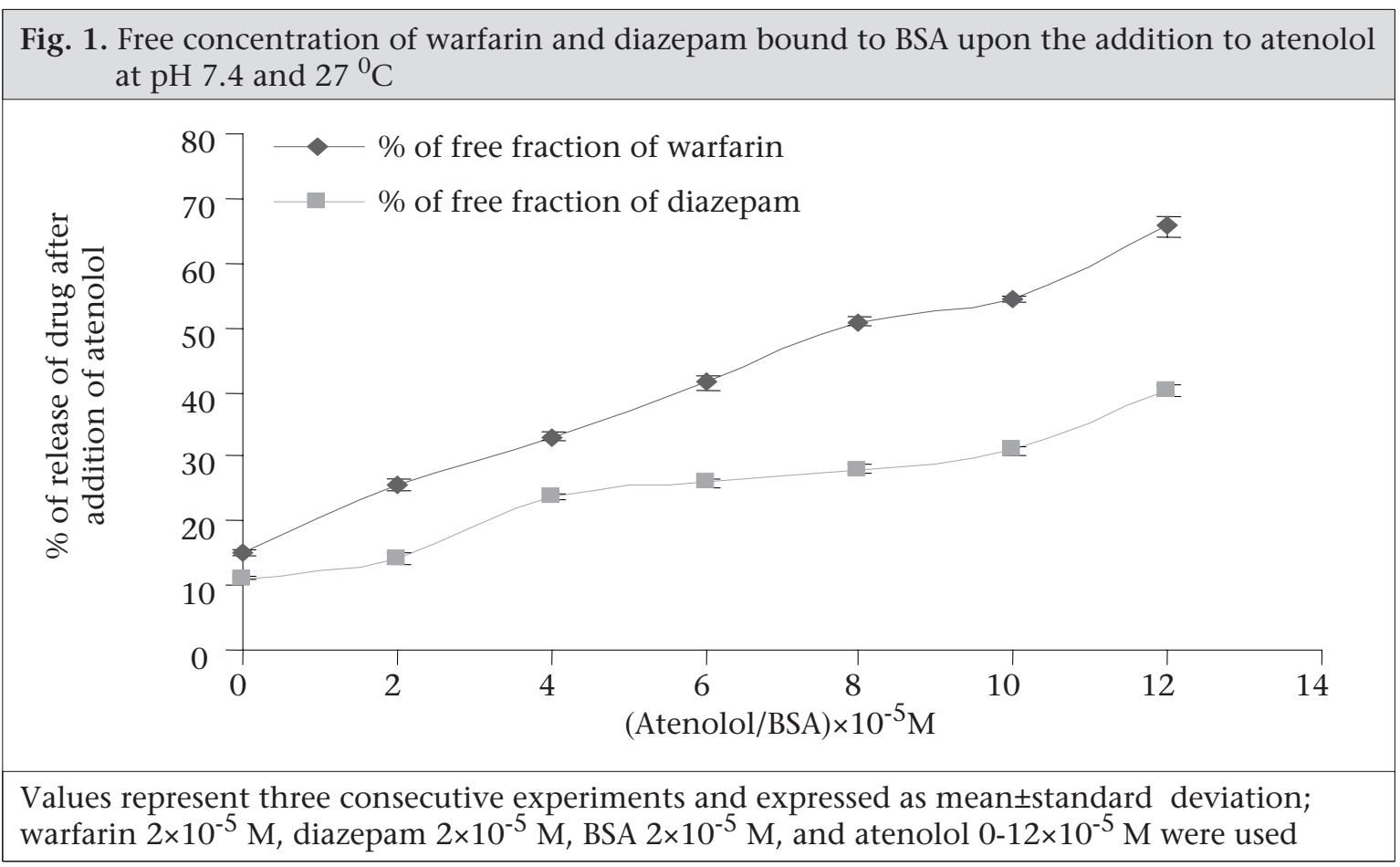

Fig. 2. Free concentration of atenolol when used with warfarin and diazepam bound to BSA at $\mathrm{pH} 7.4$ and at temperature of $27^{\circ} \mathrm{C}$

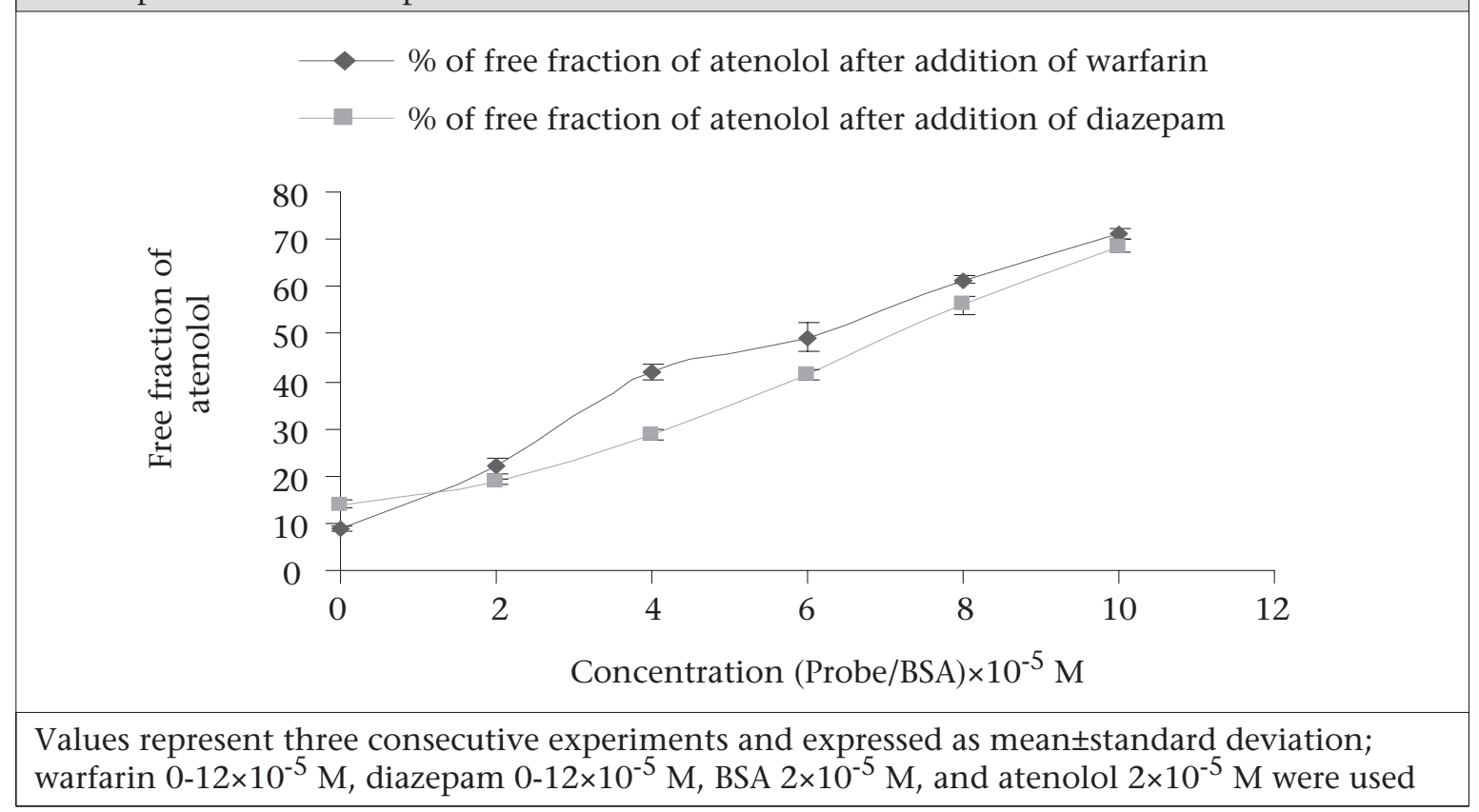

Site I of BSA but also binds with Site II to a lesser extent. In a previous experiment, it was observed that the binding of arsenic to BSA occurred at Site II (9). The displacement interaction will be prominent for the binding, occurring at the same site. It should also be accountable for the binding to opposite site as these two binding sites exist in a transitional state.

Protein-binding of some beta-blockers was de- termined in-vitro using equilibrium dialysis of labelled drug. Oxprenolol and propranolol were highly bound to serum, alprenolol, and pindolol, but timolol to a lesser degree, and atenolol, metoprolol, and sotalol were negligibly bound (25). Binding studies with beta-adrenoceptor-blocking drugs in the presence of human plasma in combination with investigations of the sympatholytic activity in 
Fig. 3. Free concentration of atenolol bound to BSA upon the addition of arsenic trioxide in absence and presence of Site I-specific probe

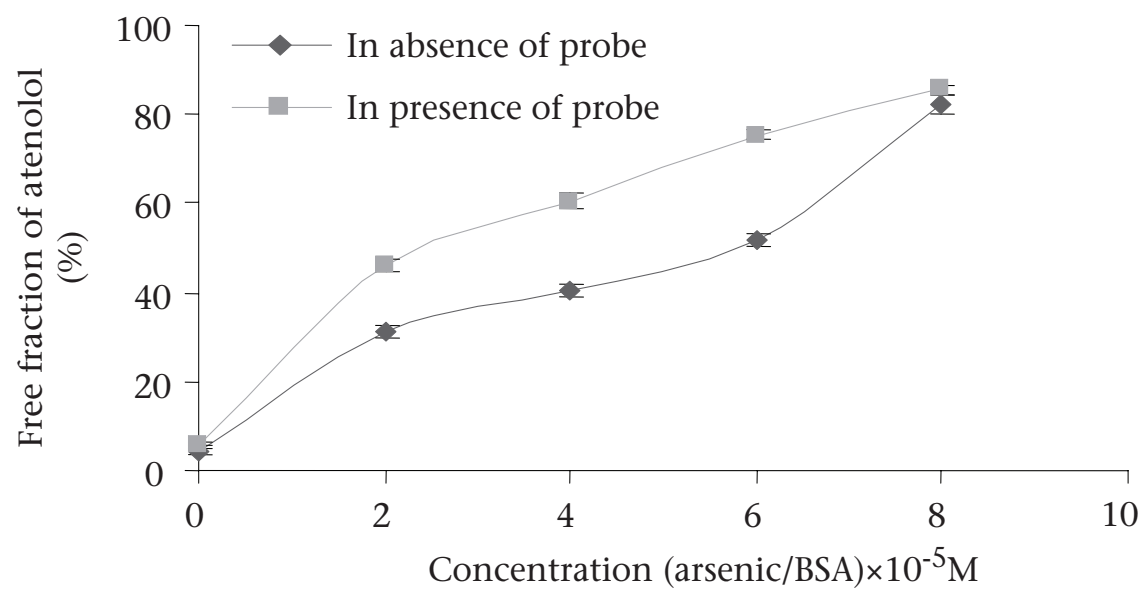

Values represent three consecutive experiments and expressed as mean \pm standard deviation; warfarin $2 \times 10^{-5} \mathrm{M}$, arsenic $0-12 \times 10^{-5} \mathrm{M}$, BSA $2 \times 10^{-5} \mathrm{M}$, and atenolol $2 \times 10^{-5} \mathrm{M}$ were used

Fig. 4. Proposed models of the atenolol-BSA-arsenic interaction in absence and presence of warfarin (Site I-specific probe)

(A) Drug interaction in absence of probe

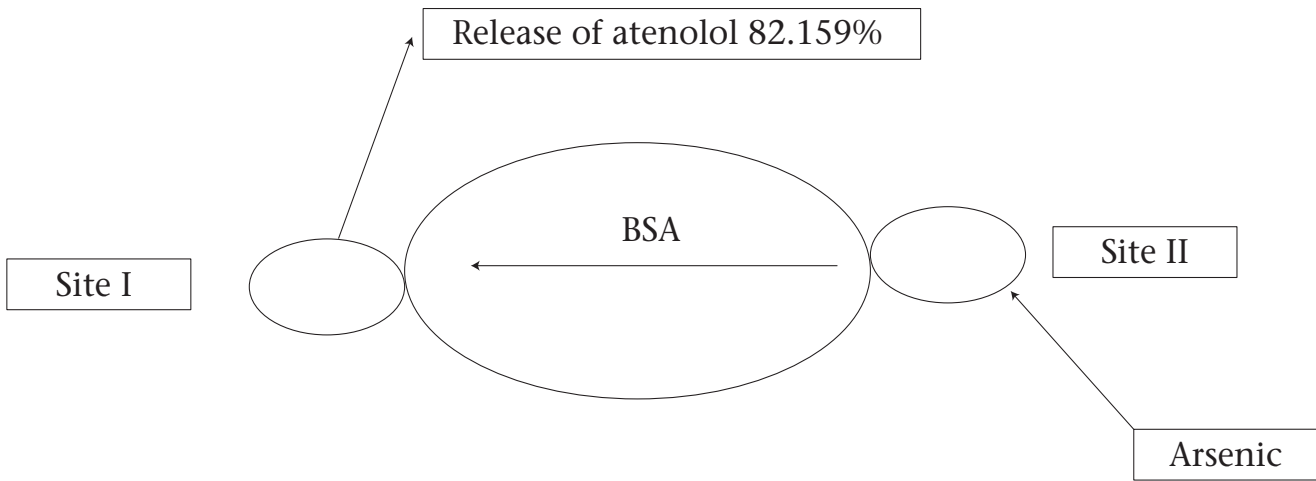

(B) Drug interaction in presence of probe

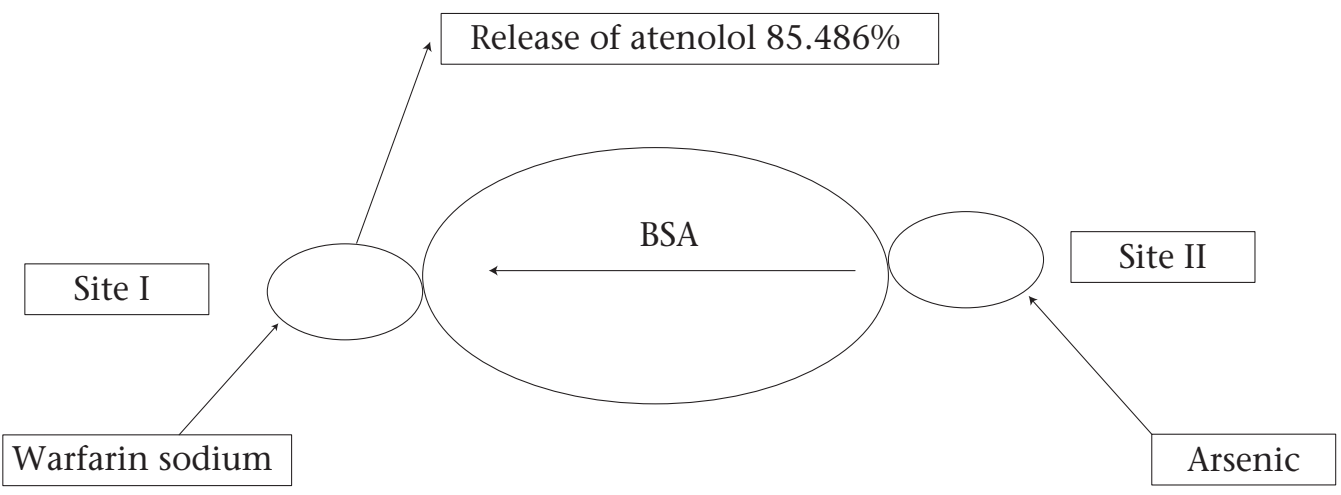

Concentrations used: $[\mathrm{BSA}]=[$ Atenolol $]=2 \times 10^{-5} \mathrm{M},[$ Arsenic $]=0-12 \times 10^{-5} \mathrm{M}$, $[$ Warfarin $]=2 \times 10^{-5} \mathrm{M}$ 
volunteers have shown that there is a correlation between plasma levels and drug action (26). This is of major importance for the duration of action which depends on dose and plasma half-life. These observations may be of clinical significance as patients with coronary heart disease, who take their drug once a day in the morning, need protection for the rest of the day. It is known that the incidence of silent ischaemic episodes, myocardial infarctions, and strokes increase in the early morning hours. Therefore, a preferential drug would guarantee a full therapeutic effect for 24 hours. B-adrenoreceptor antagonists improve acute outcomes and long-term prognosis in ischaemic heart disease (27) and reduce peri-operative events among highrisk patients undergoing major non-cardiac and vascular surgery $(28,29)$. The beta-adrenergic receptor is a glycoprotein (30). $\beta_{2}$-AR contributes to cardiovascular regulation by influencing several functions, and results of previous studies suggest that a decreased function of the $B_{2}$-AR may be involved in essential hypertension. $ß_{2}$-AR is polymorphic, and certain polymorphisms of these receptors are of functional importance (31). Stimulation of the $\beta_{1}$-AR in $\beta_{2}-A R-K O$ myocytes produces the greatest increase in contraction rate through a signalling pathway that requires protein kinase $A\left(\mathrm{P}_{K} A\right)$ activation. In contrast, stimulation of the $\beta_{2}$ $\mathrm{AR}$ in $\beta_{1}$-AR-KO myocytes results in a biphasic effect on contraction rate with an initial increase in rate that does not require $\mathrm{P}_{\mathrm{K}} \mathrm{A}$, followed by a decrease in rate that involves coupling to a pertussis toxin-sensitive $G$ protein (32). The beta-adrenergic receptor kinase (ß-ARK) specifically phosphorylates the agonist-occupied form of the beta-adrenergic and related $\mathrm{G}$ protein-coupled receptors (33). $\mathrm{Ar}$ senic-induced decreased expression of $\beta_{2}-A R$ in cultured keratinocytes has also been reported (34). Recent studies of the effects of arsenic on cardiac electrophysiology have focused on arsenic trioxide $\left(\mathrm{As}_{2} \mathrm{O}_{3}\right)$. The interest in studying arsenic trioxide is related to its use in the treatment of cancer, and some indications of heart problems associated with the treatment (35) reported that arsenic trioxide prolongs the duration of AP.

Ingested inorganic arsenic has been known to be related to the development of peripheral vascular disease and ischaemic heart disease among residents consuming water with high arsenic concentrations in Taiwan (36-39), Chile (40-42), and Mexico (43). A comparison of the prevalence of hypertension among subjects with and without arsenic exposure through drinking-water was done in Bangladesh. This study showed a dose-response relationship between inorganic arsenic exposure from drinking- water and risk of hypertension (44). The effect of long-term exposure to inorganic arsenic on the development of hypertension has rarely been studied, and the mechanism for inorganic arsenic to induce hypertension remains unclear (45). Long-term arsenic exposure has been documented to be associated with the development of peripheral neuropathy. Characteristic electromyographic changes include decreased nerve-conduction amplitude, with little changes in nerve-conduction velocity (46). Arsenic neuropathy has been classified as a distal axonopathy with axonal degeneration, especially of large myelinated fibres of both sensory and motor neurons (47).

A target of arsenite in liver-cells may be the $\mathrm{P}_{450} \mathrm{~s}$, which are gene families of haemoproteins that catalyze the oxidation of many endogenous and exogenous lipophilic chemicals (48). Earlier investigations revealed that severe exposure to arsenite reduces both basal and induced levels of some hepatic $\mathrm{P}_{450} \mathrm{~s}$ as measured spectrally or enzymatically $(49,50)$ in rodents, and in primary cultures of rat hepatocytes, it has also been found to decrease induction of $\mathrm{CYP}_{1} \mathrm{~A}_{1 / 2}, 2 \mathrm{~B} 1$, and $3 \mathrm{~A} 23$ (51). The effect of arsenite to decrease $\mathrm{P}_{450} \mathrm{~s}$ may cause major implications in human health by altering the metabolism and elimination of toxic chemicals and drugs that are substrates for such $\mathrm{P}_{450} \mathrm{~s}$. CYP3As are the most abundant $\mathrm{P}_{450}$ proteins found in the human liver, accounting for between $30 \%$ and $60 \%$ of the total cytochrome $\mathrm{P}_{450}$ content, with CYP3A4 being the major hepatic CYP3A present (52). In humans, CYP3A proteins are involved in the metabolism of $45 \%$ to $60 \%$ of all currently-used drugs $(53,54)$. Therefore, variability in CYP3A4 enzyme system expression would be expected to have a profound effect on the efficacy and safety of drugs that have a narrow therapeutic index and are metabolized by CYP3As.

It was previously reported that $5 \mu \mathrm{M}$ of arsenite not only decreases phenobarbital (PB)-induced CYP3A23 protein, with a little to no decrease in CYP3A23 mRNA, in primary cultures of rat hepatocytes (51) but also decreases CYP1A1 and CYP1A2 expression in primary human hepatocytes (55), benzo[a]pyrene-induced CYP1A1 and CYP1B1 expression in T-47D human breast-cancer cells (56), and benzo[k]-fluoranthene-mediated induction of CYP1A1 mRNA in HepG2 cells (57). Although the mechanisms underlying arsenite-mediated decrease in $\mathrm{P}_{450}$ s have yet to be identified, several hypotheses have been generated, including transcriptional and post-translational events $(56,58)$.

Arsenic has been reported to induce chronic renal 
insufficiency from cortical necrosis (59), and signs of arsenic-induced renal injury include haematuria, leukocyturia, and glycosuria (60). The arsenicrelated hypertension observed in that study is the result of possible neurological, and renal defects induced by arsenic need further exploration. Treatment for hypertension with beta-blockers in the arsenic-affected area where people are bound to drink arsenic-containing well-water daily should require additional precautions. Atenolol does not undergo hepatic metabolism and has rarely been associated with liver injury. Arsenic may cause renal insufficiency which could lead to accumulation of more atenolol in plasma because excretion of atenolol is totally dependent on renal function and increases its plasma half-life. Moreover, as shown in the present study, arsenic displaces the in-vitro atenolol binding to BSA and increases the free concentration of drug which may be available for further action upon the beta-receptor. Further research is needed to elicit the exact mechanism of drug interaction with arsenic and its binding with bovine serum albumin.

\section{REFERENCES}

1. Kober A, Sjöholm I. The binding sites on human serum albumin for some nonsteroidal antiinflammatory drugs. Mol Pharmacol 1980;18:421-6.

2. Kragh-Hansen U. Molecular aspects of ligand binding to serum albumin. Pharmacol Rev 1981;33:17-53.

3. Peters T, Jr. All about albumin: biochemistry, genetics, and medical applications. San Diego, CA: Academic Press, 1996:1-132.

4. Fehske KJ, Müller WE, Wollert U. The location of drug binding sites in human serum albumin. Biochem Pharmacol 1981;30:687-92.

5. Sjöholm I, Ekman B , Kober A, Ljungstedt-Påhlman I, Seiving B, Sjödin T. Binding of drugs to human serum albumin: XI. The specificity of three binding sites as studied with albumin immobilized in microparticles. Mol Pharmacol 1979;16:767-77.

6. Kragh-Hansen U. Effect of aliphatic fatty acid on the binding of phenol red to human serum albumin. Biochem J 1981;195:603-13.

7. Nahar Z, Rhaman MH, Hasnat A. Interaction of nifedipine with BSA: effect of metals. Bangladesh J Physiol Pharmacol 1997;13:18-20.

8. Sudlow G, Birkett DJ, Wade DN. The characterization of two specific drug binding sites on human serum albumin. Mol Pharmacol 1975;11:824-32.

9. Sudlow G, Birkett DJ, Wade DN. Further characterization of specific drug binding sites on human serum albumin. Mol Pharmacol 1976;12:1052-61.
10. Uddin SJ, Rouf R, Sen PK, Alam MA, Sarder MM, Alam SMM et al. In-vitro studies of the effect of arsenic on the binding of metronidazole at the binding sites of bovine serum albumin. Khulna Univ Stud 2005;6:73-6.

11. Uddin SJ, Shilpi JA, Murshid GMM, Rahman AA, Sarder MM, Alam MA. Determination of the binding sites of arsenic on bovine serum albumin using warfarin (site-I specific probe) and diazepam (site-II specific probe) J Biolog Sci 2004;4:609-12.

12. Alam MA, Awal MA, Mostofa M, Islam MK, Subhan N. In-vitro displacement interaction of atenolol and amlodipine on binding with bovine serum albumin when co-administered. Bangladesh J Pharmacol 2007;2:20-6.

13. Greminger P, Vetter $H$, Boerlin HJ, Baumgart $P$, Havelka J, Walger P et al. Atenolol, pindolol und propranolol bei essentieller hypertonie: ansprechquote und verträglichkeit. Schweiz Med Wochenschr 1982;112:1831-5.

14. Adamska-Dyniewska H. ß-adrenolytics—an update. Probl Ter Monit 1998;9:143-9.

15. Borchard U. Pharmacological properties of beta-adrenoceptor blocking drugs. J Clin Basic Cardiol 1998;1:5-9.

16. Telatyñska B, Wójcicki J, DroŸdzik M, Gawroñska-Szklarz B, Sulzyc-Bielicka V, Sterna R. Comparative pharmacokinetics of propranolol and atenolol in primary hyperlipidemia. Pol J Pharmacol 2003;55:81-9.

17. Sassard J, Pozet N, McAinsh J, Legheand J, Zech P. Pharmacokinetics of atenolol in patients with renal impairment. Europ J Clinl Pharmacol 1977;12:175-80.

18. Sager G, Nilsen OG, Jacobsen S. Variable binding of propranolol in human serum. Biochem Pharmacol 1978;28: 905-11.

19. Wójcicki J, Kalinowski W, Gawroñska-Szklarz B. Comparative pharmacokinetics of doxycycline and oxytetracycline in patients with hyperlipidemia. ArzneimForsch-Drug Res 1985;35: 911-93.

20. Lin JH, Cocchetto DM, Duggam DE. Protein binding as a primary determinant of the clinical pharmacokinetic properties of non-steroidal anti-inflmmatory drugs. Clin Pharmacokinet 1987;12:402-32.

21. Seedher N, Agarwal P. Reversible binding of some isoxazolyl penicillins with serum albumin using fluorescence spectroscopic technique. Indian J Pharm Sci 2006;68:327-31.

22. Singlas E. Determination of protein binding and its characteristics: protein binding of drug. Chapter 1. 2nd ed. Basel: Hoffmann-La Roche, 1987:25-31.

23. Singlas E. Protein binding of drug. Chapter 1. 2nd ed. Basel: Hoffmann-La Roche, 1987:20-2.

24. Petitpas I, Bhattacharya AA, Twine S, East M, Curry S. Crystal structure analysis of warfarin binding to hu- 
man serum albumin: anatomy of drug site I. J Biol Chem 2001;276:22804-9.

25. Belpaire FM, Bogaert MG, Rosseneu M. Binding of beta-adrenoceptor blocking drugs to human serum albumin, to alpha 1-acid glycoprotein and to human serum. Eur J Clin Pharmacol 1982;22:253-6.

26. Wellstein A, Palm D, Belz GG. Affinity and selectivity of beta-adrenoceptorantagonists in vitro. J Cardiovasc Pharmacol 1986;8(Suppl II):S36-40.

27. Ryan TJ, Antman EM, Brooks NH, Califf RM, Hillis LD, Hiratzka LF et al. 1999 update: ACC/AHA guidelines for the management of patients with acute myocardial infarction. A report of the American College of Cardiology/American Heart Association Task Force on Practice Guidelines (Committee on Management of Acute Myocardial Infarction). J Am Coll Cardiol 1999;34:890-911.

28. Wallace A, Layug B, Tateo I, Li J, Hollenberg M, Browner W et al. Prophylactic atenolol reduces postoperative myocardial ischemia. McSPI Research Group. Anesthesiology 1998;88:7-17.

29. Mangano DT, Layug EL, Wallace A, Tateo I. Effect of atenolol on mortality and cardiovascular morbidity after noncardiac surgery. Multicenter Study of Perioperative Ischemia Research Group. N Eng J Med 1996;335:1713-20.

30. George ST, Ruoho AE, Malbon CC. N-glycosylation in expression and function of beta-adrenergic receptors. J Biol Chem 1986;261:16559-64.

31. Herrmann V, Büscher R, Go MM, Ring KM, Hofer JK, Kailasam MT et al. Beta(2)-adrenergic receptor polymorphisms at codon 16, cardiovascular phenotypes and essential hypertension in whites and African Americans. Am J Hypertens 2000;13:1021-6.

32. Devic E, Xiang Y, Gould D, Kobilka B. Beta-adrenergic receptor subtype-specific signaling in cardiac myocytes from beta(1) and beta(2) adrenoceptor knockout mice. Mol Pharmacol 2001;60:577-83.

33. Benovic JL, Onorato JJ, Arriza JL, Stone WC, LohseM, Jenkins NA et al. Cloning, expression, and chromosomal localization of beta-adrenergic receptor kinase 2. A new member of the receptor kinase family. J Biol Chem 1991;266:14939-46.

34. Chang HR, Yu HS, Chai CY, Lin YR, Yu CL. Arsenic induces decreased expression of beta ${ }_{2}$-adrenergic receptors in cultured keratinocytes. Archiv Dermatol Res 1998;290:402-4.

35. Chiang CE, Luk HN, Wang TM, Ding PY. Prolongation of cardiac repolarization by arsenic trioxide. Blood 2002;100:2249-52.

36. Tseng WP. Effects and dose-response relationships of skin cancer and blackfoot disease with arsenic. Environ Health Perspect 1977;19:109-19.

37. Chen CJ, Wu MM, Lee SS, Wang JD, Cheng SH, Wu HY. Atherogenicity and carcinogenicity of high-arsenic artesian well water. Multiple risk factors and related malignant neoplasms of blackfoot disease. Arteriosclerosis 1988;8:452-60.

38. Wu MM, Kuo TL, Hwang YH, Chen CJ. Dose-response relationship between arsenic concentration in well water and mortality from cancers and vascular diseases. Am J Epidemiol 1989;130:1123-32.

39. Chen CJ. Blackfoot disease. Lancet 1990;336:442.

40. Rosenberg HG. Systemic arterial disease and chronic arsenicism in infants. Arch Pathol 1974;97:360-5.

41. Zaldivar R. Arsenic contamination of drinking water and foodstuffs causing endemic chronic poisoning. Beitr Pathol 1974;151:384-400.

42. Borgono JM, Greiber R. Epidemiological study of arsenicism in the city of Antofagasta. In: Hemphill DD, editor. Trace substances in environmental health—VA symposium. Columbia, MO: University of Missouri Press, 1972:13-24.

43. Salcedo JC, Portales A, Landecho E, Diaz R. Transverse study of a group of patients with vasculopathy from chronic arsenic poisoning in communities of the Francisco de Madero and San Pedro Districts, Coahuila, Mexico. Rev Fac Medicina Torren 1984;12:16.

44. Rahman M, Tondel M, Ahmad SA, Chowdhury IA, Faruquee MH, Axelson O. Hypertension and arsenic exposure in Bangladesh. Hypertension 1999; 33:74-8.

45. Chen CJ, Hsueh YM, Lai MS, Shyu MP, Chen SY, $\mathrm{Wu} \mathrm{MM}$ et al. Increased prevalence of hypertension and long-term arsenic exposure. Hypertension 1995;25:53-60.

46. Donofrio PD, Wilbourn AJ. Subacute arsenic toxicity presenting on clinical and electromyographic examination as Guillain-Barre syndrome. Ann Neurol 1985;18:156-7.

47. Hindmarsh JT, McCurdy RF. Clinical and environmental aspects of arsenic toxicity. Crit Rev Clin Lab Sci 1986;23:315-47.

48. Nelson DR, Koymans L, Kamataki T, Stegeman JJ, Feyereisen R, Waxman DJ et al. P450 superfamily: update on new sequences, gene mapping, accession numbers and nomenclature. Pharmacogenetics 1996;6:1-42.

49. Sardana MK, Drummond GS, Sassa S, Kappas A. The potent heme oxygenase inducing action of arsenic and parasiticidal arsenicals. Pharmacology 1981;23:247-53.

50. Albores A, Cebrian ME, Connelly JC, Bach PH, Bridges JW. Effect of arsenite on hepatic mixed-function oxidase activity in rats. Xenobiotica 1992;22:591-7. 
51. Jacobs JM, Nichols CE, Andrew AS, Marek DE, Wood SG, Sinclair PR et al. Effect of arsenite on induction of CYP1A, CYP2B and CYP3A in primary cultures of rat hepatocytes. Toxicol Appl Pharmacol 1999;157:51-9.

52. Wrighton SA, Brian WR, Sari MA, Iwasaki M, Guengerich FP, Raucy JL et al. Studies on the expression and metabolic capabilities of human liver cytochrome P450IIIA5 (HLp3). Mol Pharmacol 1990;38:207-13.

53. Li AP, Kaminski DL, Rasmussen A. Substrates of human hepatic cytochrome P450 3A4. Toxicology 1995;104:1-8.

54. Evans WE, Relling MV. Pharmacogenomics: translating functional genomics into rational therapeutics. Science 1999;286:487-91.

55. Vakharia DD, Liu N, Pause R, Fasco M, Bessette E, Zhang QY et al. Effect of metals on polycyclic aromatic hydrocarbon induction of CYP1A1 and CYP1A2 in human hepatocyte cultures. Toxicol Appl Pharmacol 2001;170:93-103.

56. Spink DC, Katz BH, Hussain MM, Spink BC, Wu
SJ, Liu N et al. Induction of CYP1A1 and CYP1B1 in T-47D human breast cancer cells by benzo[a] pyrene is diminished by arsenite. Drug Metab Dispos 2002;30:262-9.

57. Bessette EE, Fasco MJ, Pentecost BT, Kaminsky LS. Mechanisms of arsenite-mediated decreases in benzo(k)fluoranthene-induced human cytochrome P4501A1 levels in HepG2 cells. Drug Metab Dispos 2005; 33:312-20.

58. Vernhet L, Allain N, Lee Vée M, Morel F, Guillouzo A, Fardel O. Blockage of multidrug resistance-associated proteins potentiates the inhibitory effects of arsenic trioxide on CYP1A1 induction by polycyclic aromatic hydrocarbons. J Pharmacol Exp Ther 2003;304:145-55.

59. Gerhardt RE, Hudson JB, Rao RN, Sobel RE. Chronic renal insufficiency from cortical necrosis induced by arsenic poisoning. Arch Intern Med 1978;138:1267-9.

60. Hamamoto E. Infant arsenic poisoning by powdered milk. Nihon Lji Shinpo 1955;1649:3-12 (Japanese). 